Journal of the Scholarship of Teaching and Learning, Vol. 21, No. 1, April 2021, pp. 84-106.

doi: 10.14434/josotl.v21i1.30564

\title{
A Taxonomy for Developing Undergraduate Research Experiences as High-Impact Practices
}

\author{
Abbey E. Fischer \\ University of Wisconsin-Eau Claire - Barron County \\ fischeab@uwec.edu \\ Kathy R. Immel \\ University of Wisconsin Oshkosh, Fox Cities Campus \\ Kristi Wilkum \\ University of Wisconsin Oshkosh, Fond du Lac Campus \\ Laura Lee \\ University of Wisconsin Stevens Point at Marshfield
}

\begin{abstract}
The call to increase student participation in high-impact practices (HIPs) to improve student learning, satisfaction, and retention is being answered in a multitude of ways. Faculty and staff involved in undergraduate research see this as validation of their efforts, which it is. However, Kuh \& O'Donnell's (2013) work challenges research mentors to reevaluate their efforts in order to intentionally provide an even richer and more engaging research experience. Making undergraduate research a high-impact practice requires thinking inclusively about how the research experience can be scaled across the curriculum, adjusted to increase student engagement, and adapted to student preparation and desired learning outcomes. This article presents the work of a statewide multidisciplinary faculty team that developed a scalable taxonomy for incorporating high-impact practices into student learning experiences and to serve as a roadmap for designing and assessing undergraduate research experiences. The authors offer a layered taxonomy, with milestones of increasing engagement, that establishes what sets a HIP undergraduate research experience apart from other HIP experiences and what distinguishes good practices from high-impact teaching. Aligning undergraduate research experiences with best practices across disciplines, types of research opportunities, and student achievement level was a key goal in the taxonomy development. We present cases where the taxonomy was applied to research opportunities embedded in general education courses across disciplines and different modalities. In these vignettes, the utility of the taxonomy as a tool for assessing course design and teaching effectiveness is examined and common challenges in development, implementation, and assessment of student learning experiences are also explored.
\end{abstract}

Keywords: high-impact practices, undergraduate research, taxonomy, multi-disciplinary.

\section{Introduction}

Undergraduate research directly involves students in the knowledge creation processes of a discipline. Involvement in these processes has significant positive effects on students from all socioeconomic and racial backgrounds (Awong-Taylor et al., 2016; Brownell \& Swaner, 2009; Finley, 2011; Zilvinskis, 2015). Student researchers, who may have participated in one in-class research experience or perhaps in multiple opportunities of varying modalities, indicate a higher satisfaction with their learning, a deeper level of understanding, more confidence, and a greater ability to see themselves as a member of a discipline (Crews, 2013; Linn, Palmer, Baranger, Gerard, \& Stone, 2015; Lopatto, 2004). They are 
also more likely to be retained and persist to graduation (Craney et al., 2011; Jones, et al., 2010; McMahan, 2015).

\section{Table 1. High-Impact Educational Practices.}

First-Year Seminars and Experiences

Common Intellectual Experiences

Learning Communities

Writing- and Inquiry Intensive Courses

Collaborative Assignments and Projects

Undergraduate Research

Diversity/Study Away/Global Learning

Service Learning, Community-Based Learning

Internships and Field Experiences

Capstone Courses and Projects

ePortfolios

Reprinted from: Kuh, George, O’Donnell, Ken, and Carol Geary Schneider. 2017. "HIPs at Ten." Change: The Magazine of Higher Learning 49(5): 8- 16.

Kuh identified undergraduate research as a high-impact practice (HIP) in 2008 (Table 1) (Kuh, 2008; Kuh, O’Donnell, \& Schneider, 2017). HIPs are experiences that increase student engagement in their learning and positively affect student retention and graduation. Other HIPs include learning communities, service learning, and study abroad. The connecting threads amongst all HIP experiences are eight quality conditions, such as frequent feedback for improvement and meaningful interactions with others, that serve to ensure high student engagement (Table 2) (Kuh et al., 2017).

\section{Table 2. Eight Key Elements of High Impact Practices.}

1. Performance expectations set at appropriately high levels

2. Significant investment of concentrated effort by students over an extended period of time

3. Interactions with faculty and peers about substantive matters

4. Experiences with diversity, wherein students are exposed to and must contend with people and circumstances that differ from those with which students are familiar

5. Frequent, timely, and constructive feedback

6. Opportunities to discover relevance of learning through real-world applications

7. Publication demonstration of competence

8. Periodic, structured opportunities to reflect and integrate learning Reprinted from: Kuh, George, O’Donnell, Ken, and Carol Geary Schneider. 2017. "HIPs at Ten." Change: The Magarine of Higher Learning 49(5): 8- 16.

As interest and investment in HIPs have grown across higher education, there has been a movement across institutions to ensure that students complete two HIP experiences during their college careers (McMahan, 2015). Students ideally complete one of those HIP experiences during their first two years and a second in their final two years. This leads to three considerations regarding the timing and delivery of these experiences. First, students should be able to access high-impact practices, such as undergraduate research, in a variety of ways. Second, HIPs should be intentionally planned to span a student's academic career. Third, all disciplines and institutions of higher education, from twoyear campuses to top research institutions, have crucial roles to play in the delivery of HIP experiences. 
Thus, development and scaling of high-impact undergraduate research, and increasing access to it, are priorities for many colleges and universities. The taxonomy presented here is part of a multitiered tool intended to be used primarily by practitioners during the design of high-impact undergraduate research experiences. The full taxonomy provides elaboration on the universal quality conditions of any high-impact practice, while the tiers presented here address the working components of a research experience and design choices for the research processes. We assert that this scalable taxonomy allows practitioners to intentionally design more engaging research experiences for undergraduates.

\section{Modes of Undergraduate Research Experiences}

Undergraduate research often falls into one of four categories: independent study, course-embedded, program-embedded, or summer research experience. When considering undergraduate research, one most commonly thinks of the independent study option or tiered research-lab mentoring experiences; however, recent literature has shown an increase in the number and variety of course-embedded opportunities (Awong-Taylor et al., 2016; Bell, 2015; Zimbardi \& Myatt, 2014).

Each mode of undergraduate research requires a different level of social capital expenditure by the student. Social capital is the resources, information, and opportunities gained by knowing particular people and having had certain experiences; it functions as an asset by providing power and/or authority in social situations (Joshi, Aikens, \& Dolan, 2019). Differences in students' social capital can lead to uneven participation in enriching educational experiences across socioeconomic groups (Bangera \& Brownell, 2014; Martin, Simmons, \& Yu, 2013; Ovink \& Veazey, 2011). When faculty embed research into a non-research course, little social capital is required. All students enrolled in the course can participate in the research, and thus, this method significantly broadens participation across groups. Some degree programs build research into the curriculum from introduction to research courses to capstone research experiences (Powell \& Harmon, 2014; Zimbardi \& Myatt, 2014). While program-embedded experiences increase access to research, the reach is somewhat limited because students used their social capital to select and persist in the degree program. In contrast, students who have significant social capital often feel comfortable seeking and/or accepting independent study opportunities. This method, while becoming more common across institutions, provides access to the smallest number of students. Summer research experiences, similar to independent study projects, often require significant social capital due to the application and sometimes interview process. However, some summer programs specifically aim to serve the underrepresented groups, and thus increase access in that manner (Cruz, 2020).

In addition to the differences in the students' social capital expenditure, each research experience asks for varying amounts of time on task. When embedded into a content course, undergraduate research is one component of the course rather than the focus. Research is at the heart of a research-focused course, for example a methods class, but again, the student's individual research project is only a portion of the course. These two types of research experiences will have widely varying expectations on students' research time. For instance, students in a content course, like biochemistry or introduction to psychology, may complete the majority of their research during the instructional hours for a part of the semester, whereas students in a research course likely work on their project both in and out of class. Students in independent study and summer research experiences are generally more focused on the research project and spend more time on task. The most significant differences between these modes would be 1) the total number of hours spent, and 2) the number of responsibilities that occur outside the experience but concurrent to it. For both measures, summer research offers the most hours and often the most focused time on the research project.

Journal of the Scholarship of Teaching and Learning, Vol. 21, No. 1, April 2021. josotl.indiana.edu 
Finally, across the modes of undergraduate research, the mentoring relationships vary between an undergraduate researcher, their peers, and faculty or staff mentor. Curriculum- and programembedded research experiences likely occur in larger settings where the mentor works with many research students at a time; thus, these settings may reduce the amount of available one-on-one time between student and mentor. There are some instances where such research opportunities may provide small group mentoring (Carpenter \& Pappenfus, 2009), but this requires a significant investment of time by multiple faculty and staff. When there is less one-on-one time with the mentor, students may find benefits in the mentorship offered by peers and more advanced students. Such peer mentoring may be abundant in summer research experiences when undergraduate researchers spend significantly more time working on their research and potentially doing so with their peers. Furthermore, mentors often make use of the additional time on task in summer to form stronger connections with their undergraduate researchers. Lastly, the hallmark of an independent study project is that one-on-one collaboration and relationship-building with the mentor.

\section{Undergraduate Research across the Disciplines}

What counts as research can be a contentious topic across a university community. The authors of this paper represent a diverse set of disciplines: biology, chemistry, communication studies, and psychology. We contend that while undergraduate research looks different across the disciplines, the overarching goals and overall framework of the undergraduate research experiences are similar. As such, these similarities were used to create a taxonomy that applies across all disciplines. The vignettes at the end of this paper demonstrate the cross-disciplinary utility of this tool.

This framework was conceived from its inception as inclusive of all disciplines and research approaches. While some could look at what we present and see it as only applicable to researchers with an empirical bend, scholars know the research techniques and practices that serve them, and they can generally put their preference in the context of alternate ways of knowing, collecting, or analyzing data. We believe there is room for all scholars to benefit from a structure that engages them to think about their research practice.

Most often the work that undergraduate researchers and mentors do is shared with a larger community. The forum for sharing could be a gallery, concert hall, or undergraduate symposium, but demonstrating what was done is generally a core element to the research experience. Before a student or mentor can report out, the student is sometimes asked to look over artifacts, numbers, or samples from the collection. They are taught processes for making sense of that collection through analysis and interpretation. Researchers across disciplines collect "data" which could consist of lab samples, survey responses, historical artifacts, images, or individual sounds. Learning the process for collecting and cataloguing these items is often part of doing undergraduate research. Before a collection is gathered, nearly every discipline surveys the field of known work to contextualize the research they will undertake. An artist often wants to ensure that what they want to create is not a close copy of prior work, and a social scientist wants to know that the question they are considering has not been previously answered. Thus, across the disciplines, there are processes for checking that what is being created goes beyond what is known.

Undergraduate research initiates students into the research process. Through this experience, students increase their disciplinary knowledge, explore their disciplinary interests, and prepare for the next steps in their academic or professional careers (Ishiyama, 2002). These outcomes are common across the disciplines and are key benefits of the research experience.

Journal of the Scholarship of Teaching and Learning, Vol. 21, No. 1, April 2021. josotl.indiana.edu 


\section{Benefits of Undergraduate Research Experiences}

Numerous studies indicate one of the most significant benefits of undergraduate research is the mentoring relationship that develops between the student and research advisor (Craney et al., 2011; Joshi et al., 2019; Linn et al., 2015). Through this connection, the student learns more about the discipline and has an experienced professional from whom they can seek guidance on advancing in the profession. Furthermore, the mentoring connection often provides someone on campus with whom the student can discuss non-research concerns, navigate institutional processes, and ask for input on a range of topics (Bange, 2014). This relationship has been shown to be highly influential in a student's connection to their campus, retention in their major, and persistence to graduation (Craney et al., 2011; Joshi et al., 2019).

When students work with peers within research teams, they benefit from being a member of the group (Lopatto, 2010). They gain an increased sense of belonging within the discipline and, more broadly, within education, and this often leads to their own increased investment in both (Bange, 2014; Craney et al., 2011). An increased sense of belonging typically leads to better student retention in their major and at the university (Carragher \& McGaughey, 2016; Dennehy \& Dasgupta, 2017). This sense of belonging may be even more beneficial for first-generation or underserved students because it may fill a gap in their social network. These students gain a network of support that can be used to bridge gaps in knowledge, inadequate resources, and identity conflicts (Jones et al., 2010; O'Keefe, 2013). Research groups that rely on more experienced students to train incoming students provide opportunities for leadership, mentorship, and increased responsibility in project management (Lopatto, 2010). Even if the team has a flat hierarchical structure, students working in groups must coordinate their communication, work together to solve problems, and negotiate social norms (Bange, 2014; Craney et al., 2011). While these benefits are not the explicit purpose of undergraduate research, these skills contribute to a student's future success.

Additionally, undergraduate researchers gain experience in technical skills (Craney et al., 2011). Generating new disciplinary knowledge requires that students use the "tools of the trade." In a laboratory setting, students learn to use specialized equipment, prepare and manipulate samples, collect and record data, and work as a respectful lab member. Social science students may learn to design, write, administer, and analyze research questionnaires. Equally they could be trained to collect data from people via interviews, observation, focus group facilitation, or ethnographic participation, and they often have an opportunity to learn more about the IRB process at their institution. Humanities and fine arts research students also practice the skills of their professions. For example, as rhetorical scholars in training, students learn to systematically create and evaluate texts and the situational exigency, gaining skills in documenting previous examples, viewing a text, placing a text in context, thinking about impact on audience, and drawing conclusions about the impact of work.

As students actively participate in research, they learn each discipline has content knowledge to be mastered, and that the content and research must be considered within the context of other disciplines and the "real world" (Nadelson et al., 2015). Disciplinary knowledge provides the student with a foundation that includes general content knowledge, theoretical frameworks, and methodology within the field of study. Working hands-on with these components of a discipline results in students gaining a deeper understanding that will allow them to develop the skills necessary within that field. An understanding of the context is also important, such as how the discipline overlaps a broader field and the nuanced relationships to other disciplines. Opportunities to apply learning within the context of a profession or in relation to the "real world" helps to bring the discipline to life for students and allows them to see how this knowledge is relevant to their day-to-day interactions. Finally, students can share their knowledge and further strengthen it by participating in conferences, presenting their

Journal of the Scholarship of Teaching and Learning, Vol. 21, No. 1, April 2021. josotl.indiana.edu 
work, receiving feedback from others, and interacting with professionals in the field (Bange, 2014; Linn et al., 2015).

Undergraduate research is also an opportunity for students to further develop their inquiry skills (Craney et al., 2011; Henderson, Nunez-Rodriguez, \& Casari, 2011). As students work through the research process, they may develop their own original research question or may simply need to ask questions about the project to which they are assigned. Either way, students improve at identifying and articulating what is unknown and observed. Finding answers to the unknown often requires students to dive into the literature. They become better versed at scouring databases and identifying and triangulating credible and relevant sources (Henderson et al., 2011). Once they locate relevant material, students learn to interpret and apply it to their work. As the work progresses, student researchers draw conclusions based on their understanding of the field and the data they have collected. These general inquiry skills are essential not only to a single research project, but are transferrable across courses, research experiences, disciplines, and their personal lives.

As the student makes gains in technical, content, and inquiry areas, their identity as a scholar/disciplinary expert grows (Bange, 2015; Hunter, et al., 2007; Nadelson et al., 2015). Indicators of this development include increases in self-reliance, self-confidence, desire to share their work, and a sense of belonging in the disciplinary community (Nadelson et al., 2015). Students may not initially feel as though they belong to the disciplinary community; they may struggle to see themselves as a biologist, chemist, communications specialist, or psychologist. However, experience as an undergraduate researcher gives them the opportunity to "try on" the discipline, gain confidence in their abilities, and begin their journey on the path of a disciplinary expert.

\section{High-Impact Undergraduate Research}

The numerous benefits and goals of undergraduate research highlighted in this paper, and across the literature, are part of what makes undergraduate research a high-impact practice. Student immersion into a disciplinary problem with a research mentor lends itself to a highly engaging-learning experience. However, mentors do not always know how to fit the work that needs to be done on their own research to the skills and knowledge of students who want to get involved. The actual tasks assigned to a student will vary across disciplines and even students with prior research experience may not be well prepared to fit into a new project. In addition to a wide range of possible tasks is variability in the level of autonomy afforded to the student. Looking holistically, undergraduates experience inconsistency in the range of opportunities and skills gained from undergraduate research. Thus, what is missing from prior studies of undergraduate research as a HIP is a clear delineation of the components and dimensions of the research experience and what make it high impact.

In 2013, Kuh and O’Donnell identified quality conditions (Table 2) found in every HIP that promote the high engagement of students in an educational experience. Intentionally building these into the undergraduate research opportunity ensures that student researchers get an engaging HIP experience. Lee et al. have previously described operational definitions and delineated milestones for the quality conditions (2020).

Development of an undergraduate research experience as a high-impact practice includes intentional incorporation of the universal HIP quality conditions and purposeful design of the research components. One way to facilitate such design is to use a taxonomy; this encourages the research mentor to consider the goals, or outcomes, of the research and to establish learning goals for the student researchers. In addition, a taxonomy encourages the mentor to consider the student's skill level and preparation. A taxonomy promotes the systematic and planned development of the student as researcher and can be used to design, or revise, an experience that is both high impact and matched to the skills of the students and the needs and resources of the project. Additionally, with appropriately

Journal of the Scholarship of Teaching and Learning, Vol. 21, No. 1, April 2021. josotl.indiana.edu 
high expectations, the intentionally designed research experience can be used to stretch students beyond their comfort zones, thus, engaging them at a higher level while increasing their skill set.

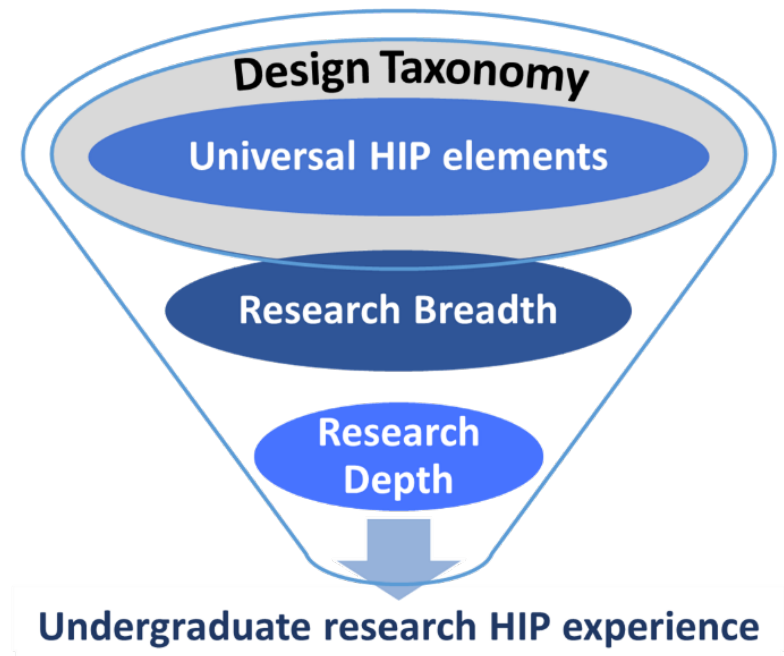

Figure 1. Overview of the taxonomy. Each oval in the funnel represents a tier of the taxonomy. Filtering an experience through the three tiers yields a HIP undergraduate research experience.

The undergraduate research taxonomy presented here is part of a three-layer system (Figure 1). By funneling the design of a learning experience through the three tiers, a research mentor can create a HIP undergraduate experience with high levels of student involvement. The first level of our taxonomy is the broadest and consists of the quality conditions, or universal HIP elements, which can be applied to any potential high-impact experience (Lee et al., 2020) Discussed below, the second and third layers of the taxonomy, research breadth and research depth elements respectively, are specific to undergraduate research and are progressively narrower in scope and focus. These layers ask the mentor to consider the level of student engagement across several criteria, including the mentormentee dynamic and selecting segments of the research process to focus on. To the extent that these choices in levels of engagement and involvement are intentional and consistent across the curriculum we can ensure that students are being provided with similar high-impact experiences while still allowing for autonomy and flexibility in the design and implementation of these experiences. 
Table 3. Research Breadth Elements - with a focus on structure. Experience design should demonstrate all research breadth elements each at a minimum of Milestone 2.

\begin{tabular}{|c|c|c|c|c|}
\hline Element & Milestone 1 & Milestone 2 & Milestone 3 & Milestone 4 \\
\hline & $\begin{array}{l}\text { Less beneficial UR } \\
\text { practices }\end{array}$ & \multicolumn{3}{|c|}{ Increasing student involvement in research } \\
\hline Originality of research & $\begin{array}{l}\text { Research answer is } \\
\text { known to student } \\
\text { and research mentor }\end{array}$ & $\begin{array}{l}\text { Research answer is } \\
\text { unknown to student but } \\
\text { known to mentor }\end{array}$ & $\begin{array}{l}\text { Research answer to faculty- } \\
\text { directed question is } \\
\text { unknown to student } \\
\text { and mentor }\end{array}$ & $\begin{array}{l}\text { Research answer to } \\
\text { student-directed } \\
\text { question is unknown to } \\
\text { student and mentor }\end{array}$ \\
\hline $\begin{array}{l}\text { Systematic disciplinary } \\
\text { inquiry }\end{array}$ & $\begin{array}{l}\text { Student inquiry into } \\
\text { trivial, rote, and/or } \\
\text { random avenues of } \\
\text { research }\end{array}$ & $\begin{array}{l}\text { Student inquiry into } \\
\text { purposeful avenue of } \\
\text { research }\end{array}$ & $\begin{array}{l}\text { Systematic student inquiry } \\
\text { into purposeful avenue of } \\
\text { research }\end{array}$ & $\begin{array}{l}\text { Systematic and } \\
\text { significant student } \\
\text { inquiry into purposeful } \\
\text { avenue of research }\end{array}$ \\
\hline $\begin{array}{l}\text { Evaluated research } \\
\text { process work }\end{array}$ & $\begin{array}{l}\text { No segment* of research } \\
\text { process assessed }\end{array}$ & $\begin{array}{l}\text { Opportunity for one } \\
\text { assessed segment of } \\
\text { research process }\end{array}$ & $\begin{array}{l}\text { Opportunities for } 2-3 \\
\text { assessed segments }\end{array}$ & $\begin{array}{l}\text { Opportunities for 4+ } \\
\text { assessed segments }\end{array}$ \\
\hline $\begin{array}{l}\text { Activities emphasize } \\
\text { research }\end{array}$ & $\begin{array}{l}\text { No activities explicitly } \\
\text { related to research }\end{array}$ & $\begin{array}{l}\text { Minimal percentage of } \\
\text { overall experience, or } \\
\text { grade, from research } \\
\text { activities }\end{array}$ & $\begin{array}{l}\text { Meaningful percentage of } \\
\text { overall experience, or } \\
\text { grade, from research } \\
\text { activities }\end{array}$ & $\begin{array}{l}\text { Entire, or nearly so, } \\
\text { overall experience, or } \\
\text { grade, based on research } \\
\text { activities }\end{array}$ \\
\hline Required project & $\begin{array}{l}\text { Either no research- } \\
\text { related projects or such a } \\
\text { project is optional }\end{array}$ & $\begin{array}{l}\text { Short research- } \\
\text { related project }\end{array}$ & $\begin{array}{l}\text { Longer research- } \\
\text { related project(s) }\end{array}$ & Full-term project(s) \\
\hline Mentoring ${ }^{\diamond}$ & $\begin{array}{l}\text { Personnel serves } \\
\text { primarily as instructor } \\
\text { rather than mentor }\end{array}$ & $\begin{array}{l}\text { Personnel serves as } \\
\text { mentor to students in large } \\
\text { groups }\end{array}$ & $\begin{array}{l}\text { Personnel serves as mentor } \\
\text { to students in small groups }\end{array}$ & $\begin{array}{l}\text { Personnel serves as } \\
\text { mentor to students on a } \\
\text { one-to-one basis }\end{array}$ \\
\hline
\end{tabular}

${ }^{*}$ Research segment $=$ literature review, formulating question, research design, data collection, data evaluate/analysis, interpreting data / drawing conclusions, or reporting out

${ }^{\diamond}$ Mentoring $=$ a professional relationship in which an experienced person (the mentor) assists another (the mentee) in developing specific skills and knowledge that will enhance the less-experienced person's professional and personal growth (Hanaway, 2020). 


\section{Research Breadth Taxonomy}

This layer of the undergraduate research taxonomy (Table 3) contains elements that provide students with a breadth of experience in undergraduate research. It focuses on the structure of the research experience and the importance of intentionally incorporating these elements to provide students with a high-impact experience, no matter the modality. Each element is operationally defined in the form of four milestones of increasing student involvement and engagement with the research process. All six elements in the research breadth taxonomy should be present at a minimum of Milestone 2 for an undergraduate research experience to be deemed high impact; activities at Milestone 1 may qualify as low-impact involvement and would be considered less beneficial to students. The research breadth elements could be incorporated into a course syllabus or a research agreement to set clear expectations. The research breadth elements are as follows:

\section{Originality of Research}

The Council on Undergraduate Research (CUR) defines undergraduate research as "an inquiry or investigation conducted by an undergraduate student that makes an original intellectual or creative contribution to the discipline" (CUR, 2021). Because the phrase "original contribution" is difficult to define, it might be most useful to focus on the state of the answer to the research question when operationally defining the milestones; who knows the answer to the research question going into the project - the student? The mentor? Both? Neither? As a research experience progresses from Milestone 1 to 4 on this element, the answer to the research question is more ambiguous, which allows student and mentor to explore concepts and ideas that are new to them. As a result, engagement of both parties should increase as they "level up" across milestones.

\section{Systematic Disciplinary Inquiry}

Systematic disciplinary inquiry seems like a daunting goal for an undergraduate research experience; however, if it is broken down into its components it is much more manageable. As the mentor structures the research experience, it is important to provide students with opportunities to seek out information and ask questions within the discipline.

Furthermore, to engage students and provide a high-impact experience, these opportunities should be structured with a plan or procedure (i.e., systematic) in place and specific goals to be achieved (i.e., purposeful). Even more engaging for students would be investigations into questions that are meaningful and significant within the discipline (Milestone 4).

\section{Evaluated Research Process Work}

The segments of the research process include literature review, formulating questions, research design, data collection, data evaluation/analysis, interpreting data/drawing conclusions, and reporting out, which are examined as depth elements of undergraduate research in the next portion of the taxonomy. In the research breadth taxonomy, this element involves embedding one or more of these segments into the undergraduate research experience and providing students with an assessment of their work. As one moves across the milestones, increasing engagement and involvement, students have opportunities to participate in additional segments of the research process. The importance of evaluation of the students' research process work is reflected in the inclusion of the word "assessed" in each of the high-impact milestones. 


\section{Activities Emphasize Research}

The undergraduate research experience should be intentionally designed to include opportunities for students to actively participate in the research process and these activities should constitute a meaningful portion of the course experience and/or grade. Furthermore, these activities should be directly related to the segments of the research process described above and engage students in research within the discipline. For example, students might engage in a structured activity wherein they develop a hypothesis and then collect data on cell phone usage amongst their peers. As the milestones increase for this element, higher levels of engagement and involvement are achieved by incorporating additional research-based activities, thereby increasing the overall percentage of the experience itself or the course grade that is focused on undergraduate research.

\section{Required Project}

A research-related project provides students with a clearly defined and structured opportunity to practice, and then demonstrate their knowledge in a particular area or their prowess in executing a segment or segments of the research process. At minimum, the undergraduate research experience should include a short research-related project. Increased engagement and involvement can be gained through longer, or even full-term, research projects that fully immerse students in the research process. For example, an independent study might be built around a semester-long research-related project, while projects of varying length might be embedded within an existing course.

\section{Mentoring}

Mentoring is "a professional relationship in which an experienced person (the mentor) assists another (the mentee) in developing specific skills and knowledge that will enhance the less-experienced person's professional and personal growth" (Hanaway, 2020). Mentoring is an important component of the undergraduate research experience as it provides students with regular contact, supervision, and feedback as they engage in the research process. Overall, students report much more positive experiences and outcomes when they have had the opportunity to work closely with a mentor (Lopatto, 2010). In addition, the mentoring relationship also has potential benefits for the mentor, both personal and professional (Hunter et al., 2007; White, 2018). The milestones for mentoring in terms of mentor to mentee ratio are somewhat set by the nature of the undergraduate research experience. For example, an independent study experience would most likely have a lower ratio than a course-embedded research experience. As the milestone increases, the availability of the mentor increases and the relationship between mentor and mentee becomes more exclusive, offering further opportunities for growth and development. 
Table 4. Research Depth Elements - with a focus on student learning outcomes. Experience design should include at least one element

at a minimum of Milestone 2. Each milestone box could read "Students have opportunities to demonstrate...."

\begin{tabular}{|c|c|c|c|c|}
\hline Element & Milestone 1 & Milestone 2 & Milestone 3 & Milestone 4 \\
\hline & Less beneficial practices & \multicolumn{3}{|c|}{ Increasing student involvement (often based on student skill level) } \\
\hline $\begin{array}{l}\text { Formulating } \\
\text { question }\end{array}$ & $\begin{array}{l}\text { Students are provided the } \\
\text { research question by the } \\
\text { research mentor }\end{array}$ & $\begin{array}{l}\text { Students select a question } \\
\text { from a mentor-provided list }\end{array}$ & $\begin{array}{l}\text { Students work in } \\
\text { collaboration with } \\
\text { the mentor to develop the } \\
\text { question }\end{array}$ & $\begin{array}{l}\text { Students are the primary } \\
\text { investigators. They develop } \\
\text { the question to be studied. }\end{array}$ \\
\hline $\begin{array}{l}\text { Data evaluation } \\
\text { / analysis }\end{array}$ & $\begin{array}{l}\text { Students apply research } \\
\text { mentor-provided methods } \\
\text { to data evaluation }\end{array}$ & $\begin{array}{l}\text { Students explain and apply } \\
\text { the mentor-provided data } \\
\text { analysis methods }\end{array}$ & $\begin{array}{l}\text { Students find and apply their } \\
\text { own data analysis methods }\end{array}$ & $\begin{array}{l}\text { Students develop and apply } \\
\text { their own data analysis } \\
\text { methods }\end{array}$ \\
\hline
\end{tabular}




\begin{tabular}{|l|l|l|l|l|}
\hline $\begin{array}{l}\text { Interpretation of } \\
\text { data / drawing } \\
\text { conclusions }\end{array}$ & $\begin{array}{l}\text { Students plug results } \\
\text { into mentor-provided } \\
\text { conclusions }\end{array}$ & $\begin{array}{l}\text { Students draw their own } \\
\text { conclusions based on results, } \\
\text { but are not asked to connect } \\
\text { the conclusions to studies } \\
\text { beyond current work }\end{array}$ & $\begin{array}{l}\text { Students draw their own } \\
\text { conclusions based on results } \\
\text { and relate the findings to } \\
\text { other relevant studies }\end{array}$ & $\begin{array}{l}\text { Students draw their own } \\
\text { conclusions based on } \\
\text { results, relate the findings to } \\
\text { other relevant studies, and } \\
\text { propose new work based on } \\
\text { current study and others' } \\
\text { work }\end{array}$ \\
\hline Reporting out & $\begin{array}{l}\text { Students only required to } \\
\text { submit worksheet-like } \\
\text { report }\end{array}$ & $\begin{array}{l}\text { Students show some } \\
\text { understanding of the subject } \\
\text { matter and basic awareness } \\
\text { of context, audience, and } \\
\text { purpose in their oral or } \\
\text { written reports }\end{array}$ & $\begin{array}{l}\text { Students present information } \\
\text { in a clear manner with fair } \\
\text { understanding of the subject } \\
\text { and adequate consideration } \\
\text { of context, audience, and } \\
\text { purpose in their oral or } \\
\text { written reports }\end{array}$ & $\begin{array}{l}\text { Students present } \\
\text { information in a clear } \\
\text { manner that displays their } \\
\text { full understanding of the } \\
\text { subject along with a } \\
\text { thorough grasp of context, } \\
\text { audience, and purpose in } \\
\text { their oral or written reports }\end{array}$ \\
\hline
\end{tabular}




\section{Research Depth Taxonomy}

When examining research depth (Table 4), the taxonomy includes each step of the research process, from formulating questions to reporting out. Each step of the research process is one element of the taxonomy with its own set of Milestones 1-4, indicating: increased expectations for students, a "deeper" involvement in the process, and (hopefully) a more engaging experience for the students. The expected milestones built into a research experience are often based upon the skill level of the students and type of research experience. In the case of research depth, not all research experiences are created equal; some may require a student to conduct the entire research process from start to finish, while others may plug students into one or two components of the process (literature review or data collection, for example), and expect them to become extremely proficient in that small subset of skills. Yet other experiences may fall somewhere in between. As a result, the authors feel that for the research depth to be considered high impact, the design of the experience should include at least one of the research depth elements at a minimum of Milestone 2. These elements are as follows.

\section{Literature Review}

A literature review is fundamental to all research. It is necessary to determine what is already known about the subject to be studied, as well as what other researchers in the field have done. Literature review may involve finding, summarizing, interpreting, and evaluating these sources. At a minimum, students can be asked to collect sources and extract direct quotes. Unfortunately, students do not always understand what they are quoting, and often use a general "cut-and-paste" mentality. Increased student involvement with literature in the field of study is seen as students are asked to move beyond simply gathering and documenting information to summarizing or evaluating/interpreting sources. As the research design moves through the milestones, students' engagement with the literature deepens, as does their understanding of the research topic.

\section{Formulating a Question}

Asking a question is easy; asking a good, testable question may be more difficult. The key to this element is the source of the research question: does it come "pre-packaged" by the facilitator, does the student choose it from a list, or is the student truly the primary investigator, developing the question to be examined completely on their own? As the experience increases in its milestone, more of the responsibility for generating the question falls on the student, with less input from the mentor. A student who generated the question is apt to be more invested in the outcome of the research and be more engaged with the overall experience.

\section{Research Design}

Research design and methodology are extremely variable, depending on the discipline, research question, and skill of the investigators. Research may involve human subjects, documents and other artifacts, living organisms, or chemical and other non-living processes. Regardless of the specifics of the methodology, the student's role in developing the details of the project is paramount. As the student plays a more integral role in developing the methodology of the study, they should be able to demonstrate a better understanding of the process and theoretical framework of the study's subject.

Journal of the Scholarship of Teaching and Learning, Vol. 21, No. 1, April 2021. josotl.indiana.edu 


\section{Data Collection}

Data collection is often a spot where students can be "plugged in" to an existing research project. It may be something mundane such as counting seeds or bacterial cultures, or something as complex as interviewing human subjects. Regardless of the discipline or subject of the study, two things are important. First, to be successful, the experience must provide the student with knowledge of discipline-specific collection procedures, equipment, and jargon. Second, context makes the work meaningful and engaging to the student; it must be evident why they are doing what they are doing and how it "fits in" to the overall research. This becomes more obvious as one increases through the milestones.

\section{Data Analysis/Evaluation}

Data analysis can often be difficult and confusing for student researchers, because it relies on potentially advanced mathematical and computing skills. However, it is vital for determining significance of data sets, and allows for explicit testing of hypotheses and determining trends and patterns in other types of data. The data analysis can be scaled to the abilities of the student researchers; careful mentoring of the research design and data collection can lead to analysis experiences that are manageable and rewarding for the student. Additionally, students can be directed toward graph and table construction as data organizational skills. In any case, as the milestones increase, more of the responsibility for finding, implementing, and developing the data analysis methods fall on the student.

\section{Interpretation of Data/Drawing Conclusions}

This is often the point where everything is tied together and research "becomes real" to the student, where they can make sense of all the numbers and observations. It is difficult for a student to do this, however, if they are simply asked to input the obtained results into conclusions provided by the mentor. As the milestones increase, the student is asked to broaden the scope of their interpretation. First, the results of the data analysis are used to accept or refute a tested hypothesis. Then, these results are put into context with what others in the field are doing. Finally, applications are made to realworld situations and other fields of study.

\section{Reporting Out}

Reporting out allows a student to share what they have accomplished with others. Indeed, public demonstrations of competence is one of Kuh's original elements of a high-impact practice (2008). Reporting can be written, oral, or visual; individually or as a group; and, shared with an internal or external audience. Reporting out can provide students with increased confidence in their content knowledge and communication abilities, and can allow them to make contact with others for future research opportunities. As the milestones increase, students are expected to include more in their reporting: deeper content knowledge, broader context, and greater understanding of audience and purpose.

This taxonomy is designed to enable the research mentor to intentionally design, evaluate, and revise any undergraduate research experience to ensure that it is high impact for students. After confirming that the experience meets the recommendations for being a high-impact practice at an acceptable level (Lee et al., 2020), the next step is to consider the research breadth and depth elements at length. Things to consider include the desired level of engagement of each element, mode of research experience being planned, skill level of the students, and amount of resources available (time, 
money, etc.). The research mentor will need to decide how many of the research depth elements will be included in the research experience, and at what milestone level. These answers may be very different for a senior capstone research project than for a first-year introductory course with research components embedded in it. With all of this in mind, a high-impact undergraduate research experience can be crafted. After implementing the HIP, the taxonomy can then be used to self-evaluate the experience and make adjustments, eventually closing the loop on the assessment process.

\section{Vignettes}

The following vignettes are presented here for a two-fold purpose. First, they demonstrate the scope and variety of undergraduate research opportunities (for beginning students). As seen here, undergraduate research occurs across a variety of disciplines (science, social science, humanities), as well as across a variety of modalities (first-year content courses, independent study, replacement for "canned" lab activities, and as a component of online instruction). It also appears as different types of experiences for the student, from stand-alone experiences to embedded full-semester projects, to smaller activities during portions of the semester. Second, they demonstrate ways in which the undergraduate research taxonomy can be used in planning and preparing an undergraduate research experience for students, as well as evaluating and modifying an experience in order to "level up" the experience for the students.

\section{Research in the General Chemistry II Lab}

Abbey E. Fischer teaches general chemistry and non-majors' chemistry courses at the two-year branch campus of the University of Wisconsin-Eau Claire - Barron County. Her research and teaching pedagogy outside of high-impact practices involve the use of food to teach important chemistry concepts.

As a faculty member, I recognize the influence that my own undergraduate research experiences have had on me, and thus, I try to provide similar opportunities to students. Prior to joining the faculty at my current institution, I mentored several students in independent study projects, senior capstones, and summer research programs. All my former research students have pursued additional research opportunities, graduate studies, and/or STEM careers. This could be judged as success.

I began working with my co-authors on how to successfully implement undergraduate research as a HIP on our two-year campuses, and it led me to reflect upon my prior performance as a research mentor. What I had viewed as student independence could be viewed as lack of direction and structure, which has been shown to decrease equity (Haak, HilleRisLambers, Pitre, \& Freeman, 2011; Supiano, 2018). The one-on-one conversations and group meetings were good but could be more regular and purposeful, which would strengthen the mentor-mentee relationship, increase student learning, and provide more structure. I could be more intentional in designing the experience, more deliberate in scaffolding skills, and more purposeful in promoting student engagement. And I could do all this while broadening student access to research.

The strength of the taxonomy, in my opinion, is the roadmap that it provided as I added a research project to the second semester lab of general chemistry. General Chemistry II at my campus typically has nine to fourteen students enrolled, and most plan to major in a STEM subject. We meet four hours for lecture and discussion, plus three hours for lab each week. The lecture curriculum is standard general chemistry material, but students spend most of the lab assisting with one of my research interests: developing undergraduate teaching labs that use food to teach chemistry concepts. I filtered this course-embedded experience through the layers of the taxonomy from the bottom (research depth) to the top (universal HIP elements) to create a rich, engaging research opportunity.

Journal of the Scholarship of Teaching and Learning, Vol. 21, No. 1, April 2021.

josotl.indiana.edu 
After two weeks of standard labs to reinforce central chemistry concepts, we switch gears to research. The campus academic librarian provides a lesson on finding relevant scholarly articles in the databases, and we discuss how to work through such articles. Students apply these skills to find articles about the benefits of undergraduate research and write a summary. This accomplishes two goals: building skills for a literature review and creating buy-in for the research experience. Using the benefits they identified, we establish two to three class goals for the research experience. Then their first intentional reflection and integration opportunity asks them to reflect upon their current mastery of those goals and how they intend to grow.

The research literature review begins with students summarizing popular press and scholarly articles that I assign. These articles provide background, context, and "real-world" connections for our work, and they serve as the basis for a discussion of the research goals. Until this point, my mentoring has been primarily to the class as a whole (Research Breadth, Mentoring Milestone 2).

Once we identify the primary research goals, students search in the literature to find methods for performing the experiments. In small research teams, they compare experimental conditions with an eye toward feasibility in the undergraduate teaching lab. Each team pitches their chosen conditions, and we reach a consensus on their next steps (Research Depth, Design Milestone 3). These small group discussions raise my mentoring to a Milestone 3, help me develop stronger connections with students, and serve as opportunities for regular and constructive feedback.

The remainder of the term is spent alternating between brief dives into the literature, pitching ideas, developing lab procedures, carrying out the agreed-upon experiments, collecting data, analyzing results, and repeating the process in light of their results. Weekly, students track their progress in their laboratory notebooks and have team check-ins with me. At least monthly, each small research team reports out to the entire class about their progress (Research Depth, Reporting Out Milestone 2), and this allows for teams to seek and provide feedback. Students take time each month to reflect on their current understanding of their work and its context, their progress toward the class skill and research goals, and how the research experience is benefitting, or could benefit, other aspects of their education and life. At the end of the term, students complete a final reflection on what they learned, skills they gained, their interest in future research opportunities, and how I could improve the experience for future students.

Students' reflections from the first two iterations of research experience suggest that they gained confidence and improved their teamwork and problem-solving skills. They also reported learning patience with themselves, their peers, and the lab work. As their research mentor, I fully concur with their self-reported gains and look forward to future offerings of this experience.

\section{Embedding Semester-Long Research Projects into Introductory Biology Courses}

Laura Lee is an associate professor in the department of Biology at the University of Wisconsin Stevens Point at Marshfield. She currently teaches courses in Botany, Zoology, Introductory Biology and Environmental Science to firstand second-year undergraduates. Long interested in course-embedded undergraduate research, she is part of a research group examining course design for high-impact undergraduate research.

One of the first labs taught in many introductory biology courses is the use of the scientific method to test hypotheses. Due to resource and time constraints, these labs are often limited to simulated experiments or short, elementary tests of simple hypotheses. I think that it is important for students to have more experience in experimental design, hypothesis testing, data collection and analysis, and scientific reporting. Therefore, I have always included short experiments into my courses, and taught simple statistics to my students to analyze their data. To create a more meaningful research experience with real-world applications, I decided to implement semester-long research projects in some of my courses. This would allow students to gain experience in experimental design and data

Journal of the Scholarship of Teaching and Learning, Vol. 21, No. 1, April 2021. josotl.indiana.edu 
analysis, as well as increase their engagement and make them feel more like "real scientists." In 2016, I began instructing my botany students to work in groups to conduct a semester-long project examining the validity of common "gardening hacks." In 2018, I expanded the assignment to my Introductory Biology course, broadening the scope to include any biology-related "life hack."

In both courses, students now begin with a simple "scientific method" lab during the first week of the semester. The first assignment (due in week 3) requires them to use this knowledge to explore the internet, ask a question about a gardening or life "hack," propose a testable hypothesis and prediction, and design an experiment to test it. As the semester proceeds, additional research skills are taught and practiced, and scaffolded into additional assignments: literature and citations (due in week 5), graphing or data analysis (due in week 11), and outlining the paper or talk (due in week 13). In each course, this process culminates in a "display of competence," either with a group paper written in scientific-journal style or in a group oral presentation to the class, in the style of a conference presentation. In both cases, all the component parts of the project (including the final product) sum to 100 points, equivalent to an exam. Although students are given some in-class time to work on their projects, much of the work is done outside of class, and students are given access to greenhouse and lab space as needed. Because class sizes at my institution are fairly small, I am able to meet with individuals and groups as needed.

The design of this course-embedded research did not begin fully formed in each class. The original botany project was fairly bare bones in its first incarnation, with little scaffolding and primarily summative feedback. After working with my research group to design the high-impact undergraduate research taxonomy, I realized the possibility for improving and expanding the project. In 2018, I used the undergraduate research taxonomy to self-evaluate the design of my botany course with an eye to the undergraduate research component. I put the course through all three levels of the taxonomy's funnel (universal HIP elements, research breadth and research depth), in order to evaluate my course design. For each element of each level of the taxonomy, I identified my course's current milestone, and provided a rationale for each milestone score. I then reflected on my satisfaction with each of these milestone scores, as well as any constraints implicit in the experience (student skill level, time constraints, etc.). Given these constraints, I considered how I could "level up" some of the milestones and thus, student engagement in the experience. I made changes to the botany course in response to student feedback and this taxonomy activity, including more deliberate scaffolding and clarification of the citation/literature search component via a visit from the campus librarian. I also attempted to alleviate a common problem that students have with hypotheses and predictions by giving formative feedback on this component; students were required to restate their hypotheses and predictions on each assignment, hopefully revising them in response to previous feedback.

When I expanded the semester research project into my Introductory Biology course, I was better prepared and used my prior experiences to craft a better design from the start. I incorporated the scaffolded assignments and feedback into the first iteration, but later made some changes as well. Because these students were often non-majors and did not have sufficient math backgrounds, I did not attempt to teach them statistics, but concentrated on a graphing component instead. This also allowed them to be more successful in their final project, a group oral presentation rather than a scientific paper write-up, and by practicing the broader skill of public speaking and the more specific skills associated with scientific presentations. In both courses, students celebrated successes and struggled with failures, but emerged with closer relationships with their peer groups and a better understanding and appreciation of the way in which science works.

Journal of the Scholarship of Teaching and Learning, Vol. 21, No. 1, April 2021. josotl.indiana.edu 


\section{Enriching a Content Course in Psychology through Undergraduate Research}

Kathy R. Immel is an associate professor of Psychology at University of Wisconsin Oshkosh, Fox Cities Campus. She teaches general psychology, psychology of abnormal behavior, and developmental psychology. Her interest in undergraduate research prompted her to join a working group for her institution's reimagined associate degree that was focused on undergraduate research as a high-impact practice. This multi-disciplinary team of faculty members created a three-layer taxonomy to be used in designing and assessing high-impact undergraduate research experiences.

How has the taxonomy impacted my approach to undergraduate research in the psychology courses that I teach? Before I had the taxonomy as a guide, my approach to integrating undergraduate research in my general psychology course was rather haphazard. I would try different things each semester, adding new assignments and activities, but never measuring student learning outcomes or looking at the impact on engagement in my students.

When I joined our faculty working group, I made a commitment to undergraduate research. With the taxonomy in hand, I took an intentional approach to incorporating this high-impact practice in my general psychology course. For me, the specific steps involved in this deliberate process are planning, implementation, review, and revision, and our taxonomy is at the center of each step in the process.

As I plan the course, I look at each layer of the taxonomy. First, I carefully consider which milestones I want my students to achieve for each of the elements of high-impact practices. The first time I taught the course with embedded undergraduate research, most of these elements (e.g., performance expectations, investments of time, and diversity) were at Milestone 2, just reaching the level of high-impact practices. Over time, I have "leveled up" within some of the elements. For example, increasing student engagement in areas, such as opportunities to reflect and integrate learning, and real-world applications. The second layer of the taxonomy, which details the breadth elements of undergraduate research, focuses my attention on the structure of the class itself. To incorporate these elements effectively and involve my students in the research process, I have them work in small groups (4-6 students) on a research-related project. Finally, I decide which depth elements will be the focus of our research experience. I started very tentatively with students doing a literature review, and have since added other elements to provide students with further opportunities to participate in the research process. In addition, the planning step includes a careful consideration of contextual factors, including class size, student body composition, and classroom dynamics. I also consider the resources that I have available, both course-related and personal, to devote to the class. Each of these factors has a significant effect on the choices I make regarding the level of student engagement for each layer of the taxonomy.

The second step is implementation and again, the taxonomy plays a central role as I track my students' progress toward the milestones I have established. I take detailed notes during the implementation phase, looking at where students are making progress (i.e., what works), grading time, and student feedback, and I adjust along the way. For example, the literature review that I assigned to individual students was a "bear" to grade, student feedback was not positive, and learning gains were negligible. Students were much more receptive to working in small groups on a research question of their own choosing, with assigned roles for reviewing the literature.

Step three is a thorough review of the course utilizing several data points, including student grades, feedback from course evaluations, student surveys on the research process, and careful examination of the notes that I took during the implementation phase. I look for key themes related to class climate, learning objectives, assignments, grading, and course expectations. The framework of the taxonomy is the backdrop for my review and the data points that I have collected allow me to pinpoint the milestones that I achieved. I am also able to examine any discrepancies between the

Journal of the Scholarship of Teaching and Learning, Vol. 21, No. 1, April 2021. josotl.indiana.edu 
milestones I identified in the planning stage and the milestones actually achieved by the end of the term.

The final step, revision, leads me back once more to the taxonomy as I revisit the milestones of engagement for the HIP elements, student involvement in the undergraduate research breadth elements, as well as the depth elements that I chose to include. With the student learning outcomes in mind, I carefully consider changes to the course materials, with a thorough examination of class composition and layout, activities, assessments, resources, and content coverage. Each of these factors can significantly impact the choices I make regarding the milestones of engagement for each element and the depth elements of undergraduate research I include.

With each iteration of the class, I learn new things about my students, myself, and undergraduate research. While careful planning often leads to a smooth implementation, there are some bumps along the way. When issues come up, I find it helpful to do a midterm review, seeking student feedback, and referring to the taxonomy to make the necessary adjustments to get back on track. With the taxonomy as my guide, I now take a much more intentional approach to course design and implementation to ensure a high-impact undergraduate research experience for my students.

\section{Undergraduate Research in an On-line, Asynchronous Humanities Course}

Kristi Wilkum is an associate professor in the Department of Communication Studies, University of Wisconsin Oshkosh, Fond du Lac Campus. An interpersonal communication scholar by training, she has focused research on including technology and undergraduate research into early college curricula. In this project, she is focused on incorporating undergraduate research in an online bumanities course that is taken by first-and second-year students. There is no prerequisite for the course.

Incorporating undergraduate research in a humanities-based course required a reframing of the taxonomy language. There must be a tacit understanding that close reading is a methodology; data includes comparison texts form the historical record or contemporary context; analysis consists of finding patterns and omissions across texts. Undergraduate research in the humanities looks different in the method, sample, and analysis. When done well, it is rigorous, depends on evidence, and generates new insights.

A lack of rigor and quality led me to redesigning my undergraduate pop culture course to include a rhetorical research project. In a fully online format, students were charged with using rhetorical theories to understand a sample text they had selected for analysis. As beginners in rhetorical critique, the claims being made were muddled, the investigations of the text were weak, and the use of theory was nearly absent. I needed to move them toward deep use of rhetorical theory as both a technique for engaging with the text and a tool for focusing their own observations.

Applying the undergraduate research breadth taxonomy revealed areas of deficit in the course. The short papers initially taught basic rhetorical skills, but the skills, text, and theories were not explicitly linked. Each paper was an individual task. Student likely encountered the topics, theories, and assignments as if they were driven by the mode of delivery (music, movie, social media, etc.).

Applying the undergraduate research depth taxonomy called for a narrowing and focusing of skills that were being taught in this course. It was not reasonable to expect students at the freshman and sophomore level to become proficient in forming the research question, gathering data, analyzing and interpreting the results, and becoming skilled writers. Concentrating on a smaller range of skills, focused the assignments to build cumulatively upon each other. Skills that were no longer the focus were simplified and directive feedback was provided to move the student more efficiently to where they need to be. For example, the process for formulating an original research question and selecting theory were simplified and scaffolded to allow more time for students to focus on analysis. Likewise,

Journal of the Scholarship of Teaching and Learning, Vol. 21, No. 1, April 2021. josotl.indiana.edu 
a visual presentation of the argument and texts were used to showcase the analysis. This allowed the students to present the featured skill set.

The scaffolding of research steps enhances the students' skill in analysis and interpretation. Students learn the skills of seeing the most obvious layers of meaning and the subverted interpretations of the text. They learn to draw some conclusion about what they are seeing based on collected evidence from the text and context. Every assignment, discussion, and reading supports these two featured skills.

The course, through several iterations, has evolved to include a project that starts in the fourth week and runs through the end of the semester. Students begin early in the class identifying a text that they find interesting. In a series of subsequent assignments, they think about how to contextualize the text using similar texts, identify the questions their theory invites, and move through iterative cycles of describing and noticing elements of the text. While this is happening, the shorter papers and discussions in the course enable them to practice the skills they need for the final project. A discussion board requires the class to participate in writing research questions; another simulates the deep reading of a text as a class activity. One of the short papers focuses on placing a text in context and viewing it from multiple standpoints including the creator, intended and unintended audiences, historically, etc.

The semester project cumulates in a visual presentation of students' work to their peers through a discussion board. The final discussion in the course requires students to compare and contrast showcases of their work and challenges them to extend their analytical skills across showcases. They are charged to notice how the same theory produces similar, and novel, results when applied to different texts. This final bit of analysis solidifies their learning about their theory through conversation with other students using the same theory. They also compare their projects to those who used another theory to see similarities and differences. They finish the course with a metacognitive reflection about the final project and how it (mis)aligns with the course objectives.

\section{Conclusion}

In summary, students reap numerous benefits from participating in undergraduate research, and further benefits, including increased levels of engagement and involvement, emerge from making these high-impact experiences. We have created and presented a taxonomy that can be used for the design and implementation of high-impact undergraduate research experiences. The benefits of using the taxonomy are threefold. First, it can be used to scale high-impact experiences across the curriculum. Second, it can be used to intentionally set learning outcomes and an appropriate level for student engagement. Third, it provides flexibility in designing and adapting research experiences in response to varying degrees of student skill level and preparation. One of the challenges in developing a comprehensive taxonomy of this nature lies in designing a tool that is useful across various modalities and disciplines. The flexibility of this taxonomy, in this regard, can be heard in the vignettes where we shared our experiences, across different modes and disciplines, in designing high-impact undergraduate research offerings for our students. Although the utility of the taxonomy in other modalities (e.g., independent study, or summer research experience) and with student populations outside of our campuses has yet to be demonstrated, there is no reason to believe that it would not be as applicable in these scenarios as well.

\section{Acknowledgements}

The authors would like to thank Nate Maddux, assistant professor at University of Wisconsin Whitewater at Rock County, for his contributions to this working group when we began our research

Journal of the Scholarship of Teaching and Learning, Vol. 21, No. 1, April 2021. josotl.indiana.edu 
into how to successfully implement undergraduate research as a HIP within University of Wisconsin Colleges.

\section{References}

Awong-Taylor, J., D’Costa, A., Giles, G., Leader, T., Pursell, D., Runck, C., \& Mundlie, T. (2016). Undergraduate Research for All: Addressing the Elephant in the Room. CUR Quarterly, 37(1), 11-19. Retrieved from https://www.cur.org/what/publications/journals/curq/issues/

Bange, J. (2014). Undergraduate Research in the Sciences as a Series of Transformative Opportunities. Fine Focus, 1, 78-87. Retrieved from https://cardinalscholar.bsu.edu/handle/123456789/201342

Bangera, G., \& Brownell, S. E. (2014). Course-based undergraduate research experiences can make scientific research more inclusive. CBE Life Sciences Education, 13(4), 602-606. https://doi.org/10.1187/cbe.14-06-0099

Bell, J. E. (2015). A practical guide to course-based undergraduate research experiences. Retrieved from http://home.sandiego.edu/ josephprovost/bmb20989-sup-0001-suppinfo01.pdf

Brownell, J. E., \& Swaner, L. (2009). Outcomes of High-Impact Educational Practices: A Literature Review. Diversity \& Democracy, 12(2). Retrieved from https:/ /www.aacu.org/publicationsresearch/periodicals/outcomes-high-impact-educational-practices-literature-review

Carpenter, N. E., \& Pappenfus, T. M. (2009). Teaching research: A curriculum model that works. Journal of Chemical Education, 86(8), 940-945. https://doi.org/10.1021/ed086p940

Craney, C., McKay, T., Mazzeo, A., Morris, J., Prigodich, C., \& De Groot, R. (2011). Crossdiscipline perceptions of the undergraduate research experience. Journal of Higher Education, 82(1), 92-113. https://doi.org/10.1353/jhe.2011.0000

Crews, A. (2013). A Partnership for the Future: Undergraduate Research's Mutual Benefits for Students and Administrators. CUR Quarterly, 33(3), 3-6. https://doi.org/10.7748/phc2014.04.24.4.16.s15

Cruz, U. of C. S. (2020). STEM Diversity Programs. Retrieved from http://stemdiv.ucsc.edu/resources1/internshipspost-bacs/undergraduate-summer-reasearch/

CUR. (2021). Mission and Vision. Retrieved April 28, 2021, from https://www.cur.org/who/organization/mission_and_vision/

Finley, A. (2011). Assessment of High-Impact Practices: Using Findings to Drive Change in the Compass Project. Peer Review, 13(2). Retrieved from https://www.aacu.org/publicationsresearch/periodicals/assessment-high-impact-practices-using-findings-drive-change

Haak, D. C., HilleRisLambers, J., Pitre, E., \& Freeman, S. (2011). Increased structure and active learning reduce the achievement gap in introductory biology. Science, 332(6034), 1213-1216. https://doi.org/10.1126/science.1204820

Hanaway, M. (2020). An Existential Approach to Leadership Challenges. New York: Routledge.

Henderson, F., Nunez-Rodriguez, N., \& Casari, W. (2011). Enhancing Research Skills and Information Literacy in Community College Science Students. The American Biology Teacher, 73(5), 270-275. https://doi.org/https://doi.org/10.1525/abt.2011.73.5.5

Hunter, A.-B., Laursen, S., \& Seymour, E. (2007). Becoming a Scientist: The Role of Undergraduate Research in Students' Cognitive, Personal, and Professional Development. Science Education, 91(1), 36-74. https://doi.org/10.1002/sce

Ishiyama, J. (2002). Does Early Participation in Undergraduate Research Benefit Social Science and Humanities Students? College Student Journal, 36(3), 380. Retrieved from https://www.researchgate.net/publication/237386612_Does_Early_Participation_in_Undergr aduate_Research_Benefit_Social_Science_and_Humanities_Students 
Jones, M. T., Barlow, A. E. L., \& Villarejo, M. (2010). Importance of undergraduate research for minority persistence and achievement in biology. Journal of Higher Education, 81(1), 82-115. https://doi.org/10.1353/jhe.0.0082

Joshi, M., Aikens, M. L., \& Dolan, E. L. (2019). Direct ties to a faculty mentor related to positive outcomes for undergraduate researchers. BioScience, 69(5), 1-9. https://doi.org/10.1093/biosci/biz039

Kuh, G. D. (2008). High-Impact Educational Practices. In High-Impact Educational Practices: What They Are, Who Has Access to Them, and Why They Matter. Washington, DC: Association of American Colleges and Universities.

Kuh, G. D., \& O’Donnell, K. (2013). Ensuring Quality \& Taking High-Impact Practices to Scale. Washington, DC: Association of American Colleges and Universities.

Kuh, G. D., O’Donnell, K., \& Schneider, C. G. (2017). HIPs at Ten. Change: The Magazine of Higher Learning, 49(5), 8-16. https://doi.org/10.1080/00091383.2017.1366805

Lee, L., Wilkum, K., Immel, K. R., \& Fischer, A. E. (2020). A Taxonomy for Designing and Evaluating High-Impact Practice Experiences. College Teaching, O(0), 1-11. https://doi.org/10.1080/87567555.2020.1846487

Linn, M. C., Palmer, E., Baranger, A., Gerard, E., \& Stone, E. (2015). Undergraduate research experiences: Impacts and opportunities. Science, 347(6222). https://doi.org/10.1126/science.1261757

Lopatto, D. (2004). Survey of Undergraduate Research Experiences (SURE): First Findings. Cell Biology Education, 3(4), 270-277. https://doi.org/10.1187/cbe.04-07-0045

Lopatto, D. (2010). Undergraduate Research as a High-Impact Student Experience. AAC\&U Peer Review, 12, 27-30. Retrieved from https://www.aacu.org/publicationsresearch/periodicals/undergraduate-research-high-impact-student-experience

Martin, J. P., Simmons, D. R., \& Yu, S. L. (2013). The role of social capital in the experiences of hispanic women engineering majors. Journal of Engineering Education, 102(2), 227-243. https://doi.org/10.1002/jee.20010

McMahan, S. (2015). Creating A Model For High Impact Practices At A Large, Regional, Comprehensive University: A Case Study. Contemporary Issues In Education Research - Second Quarter, 8(2). https://doi.org/https://doi.org/10.19030/cier.v8i2.9144

Nadelson, L. S., Warner, D., \& Brown, E. (2015). Life's Lessons in the Lab : A Summer of Learning from Undergraduate Research Experiences. Journal of STEM Education, 16(3), 5-12. Retrieved from https://jstem.org/jstem/index.php/JSTEM/article/view/1891

O'Keefe, P. (2013). A Sense of Belonging: Improving Student Retention. College Student Journal, 47(4), 605-614. Retrieved from https:/ / researchrepository.rmit.edu.au/esploro/outputs/journalArticle/A-sense-of-belongingImproving-student-retention/9921862552801341

Ovink, S. M., \& Veazey, B. D. (2011). More Than "Getting Us Through:” A Case Study in Cultural Capital Enrichment of Underrepresented Minority Undergraduates. Research in Higher Education, 52(4), 370-394. https://doi.org/10.1007/s11162-010-9198-8

Powell, N. L., \& Harmon, B. B. (2014). Two-year community: Developing scientists--a multiyear research experience at a two-year college. Journal of College Science Teaching, 44(2), 11-17. Retrieved from https://my.nsta.org/resource/?id=10.2505/4/jcst14_044_02_11

Supiano, B. (2018). Traditional Teaching May Deepen Inequality. Can a Different Approach Fix It? Chronicle of Higher Education. Retrieved from https://www.chronicle.com/article/TraditionalTeaching-May/243339

White, A. (2018). Understanding the University and Faculty Investment in Implementing High-

Journal of the Scholarship of Teaching and Learning, Vol. 21, No. 1, April 2021. josotl.indiana.edu 
Fischer, Immel, Wilkum, and Lee

Impact Educational Practices. Journal of the Scholarship of Teaching and Learning, 18(2), 118-135. https://doi.org/10.14434/josotl.v18i2.23143

Zilvinskis, J. (2015). Using Authentic Assessment to Reinforce Student Learning in High-Impact Practices. Assessment Update, 27(6), 7-8, 12-13. https://doi.org/10.1002/au

Zimbardi, K., \& Myatt, P. (2014). Embedding undergraduate research experiences within the curriculum: a cross-disciplinary study of the key characteristics guiding implementation. Studies in Higher Education, 39(2), 233-250. https://doi.org/10.1080/03075079.2011.651448 